\title{
PENINGKATAN KINERJA AUDIT INTERNAL DENGAN METODE EVALUASI DI SEKSI QUALITY ASSURANCE (QA) PT. SURYA TOTO INDONESIA Tbk.
}

\author{
Mohamad Solihudin dan Zulfa Fitri Ikatrinasari \\ Program Studi Magister Teknik Industri, Universitas Mercu Buana \\ e-mail: soleh0282@gmail.com,zulfafitri@gmail.com
}

\begin{abstract}
ABSTRAK
PT. Surya Toto Indonesia Tbk. sebagai salah satu perusahaan manufaktur yang bergerak dibidang plumbing fitting mempunyai keinginan untuk terus berkembang dan memposisikan TOTO sebagai merek kelas dunia. Dengan demikian perlunya perusahaan mengukur dan meningkatkan kinerja karyawan dan organisasi yang ada didalamnya. Tujuan dari penelitian ini adalah pengukuran kinerja organisasi atau seksi Quality assurance (QA) pada sub seksi AMI (Audit Mutu Internal). Mengukur kinerja organisasi seksi QA dilakukan dengan cara mengukur hasil pedoman kerja supervisor seksi. Pengukurannya dilakukan setiap bulan dan dievaluasi per 6 bulan pertama (semester 1) dan 6 bulan ke dua (semester 2). Pedoman kerja supervisor QA dibuat berdasarkan top down dari pedoman kerja direktur dan pedoman kerja manajer. Didalamnya terdiri dari unsur atau item Quality, Cost, Delivery, Safety, Morality, Environment (QCDSME). Berdasarkan data hasil audit Internal tahun 2014, jumlah temuan kategori Improvement masih rendah yaitu 1,96\% dari jumlah total temuan audit serta mempertimbangkan target manajemen yang dituangkan dalam pedoman kerja supervisor QA tahun 2015 yaitu target temuan audit internal kategori improvement adalah 40\% dari jumlah total temuan audit, maka keputusan manajemen untuk peningkatan kinerja audit internal. Dengan melakukan pelatihan terhadap personal auditor internal yaitu pendidikan proses produksi, pemahaman sistem, konsep 5Why, problem solving serta membuat form laporan audit dengan konsep 5 why dan menentukan jobdescription audit internal, hasil temuan audit internal untuk kategori OI (Opportunity Improvement) pada semester I naik menjadi 41\% dengan demikian auditor internal dapat memberikan kontribusi terhadap tujuan perusahaan untuk melakukan continuous improvement disegala bidang.
\end{abstract}

Kata Kunci: Audit Internal, Continuous Improvement, Kinerja Organisasi.

\begin{abstract}
PT. Surya Toto Indonesia Tbk. as one manufacturing company engaged in plumbing fittings have a desire to continue to grow and TOTO position as a world-class brand. Thus the need for companies to measure and improve the performance of employees and organizations that is inside. The purpose of this study was the measurement of the performance of the organization or section Quality assurance (QA) in subsections AMI (Internal Quality Audit). Measuring organizational performance QA section was done by measuring the results of work guidance section supervisor. The measurements were carried out every month and evaluated per the first 6 months (first half) and 6 months to two (2 semesters). QA supervisor working guidelines are based on a top down of guidelines directors and managers working guidelines. Involves a series of elements or items Quality, Cost, Delivery, Safety, Morality, Environment (QCDSME). Based on data from the Internal audit in 2014, the number of findings Improvement category was still low at 1.96\% of the total number of audit findings and consider the management targets as outlined in the QA supervisor working guidelines in 2015 that is the target of the findings of the internal audit improvement category is $40 \%$ of the total amount audit findings, the management's decision to increase the performance of internal audit. By doing training on personal internal auditors namely education production process, understanding the system, the concept 5Why, problem solving and create a form of audit reports with the concept of 5 why and determine jobdescription internal audit, the findings of the internal audit for the category OI (Opportunity Improvement) in the first half rose to $41 \%$ thus the internal auditor can contribute to the company's goals to make continuous improvement in all fields.
\end{abstract}

Keywords: Internal Audit, Continuous Improvement, Organizational Performance.

\section{PENDAHULUAN}

Seiring dengan meningkatnya persaingan di era globalisasi ini maka tantangan terbesar bagi suatu perusahaan dituntut untuk menjamin kepuasan pelanggan baik itu dari segi jasa pelayanan maupun infrastruktur penunjangnya. Jika ingin bersaing maka masing-masing organisasi perusahaan diharapkan mampu dalam memberikan pelayanan yang prima. PT. Surya Toto Indonesia Tbk. sebagai salah 
satu perusahaan manufaktur yang bergerak di bidang plumbing fitting mempunyai keinginan untuk terus berkembang dan memposisikan TOTO sebagai merek kelas dunia. Untuk mewujudkan keinginanya perusahaan telah banyak melakukan perubahan-perubahan perbaikan disegala bidang dengan melakukan program continous improvement serta perusahan terus berupaya untuk selalu meningkatkan kinerja dari para karyawannya baik kinerja personal (individu) maupun kinerja dari organisasi organisasi yang ada didalamnya. Dengan mengukur kinerja karyawan baik yang sifatnya personal (hasil kerja individu) maupun kinerja organisasi departemen atau seksi, maka manajemen bisa membuat keputusan-keputusan strategis untuk meningkatkan kinerja karyawan maupun kinerja organisasi seksi. Kinerja organisasi departemen yang saat ini perlu ditingkatkan adalah departemen atau seksi Qualiaty Asurance (QA) yaitu peningkatkan kinerja pada subseksi AMI dalam rangka pengawasan dan pengendalian sistem kerja organisasi-organisasi departemen atau seksi PT. Surya Toto Indonesia Tbk. serta menilai efisien dan keefektifan dari pelaksanaan struktur pengendalian intern perusahaan, kemudian memberikan hasil berupa saran atau rekomendasi dan memberi nilai tambah bagi manajemen yang akan dijadikan landasan mengambil keputusan atau tindak selanjutnya, disamping itu, audit internal juga bisa membantu perusahaan untuk memberikan masukan keseksi atau organisasi yang diaudit dengan menggali peluang-peluang seksi untuk melakukan improvement sebagai salah satu program perusahaan yang berkelanjutan maka pimpinan membutuhkan adanya peningkatan kinerja internal auditor yang lebih baik dalam rangka meningkatkan jumlah temuan audit internal kategori OI (opportunity improvement).

Audit internal merupakan suatu aktivitas konsultasi yang dikelola secara independen dan objektif, yang dirancang sebagai penambah nilai untuk meningkatkan kegiatan operasional perusahaan [1]. Secara efektif, auditor internal menyediakan informasi yang dibutuhkan manajer dalam melaksanakan tanggung jawab. Masih menurut Sawyer penilaian secara independen dilakukan auditor internal pada suatu perusahaan untuk menilai kegiatan operasional dengan mengukur dan mengevaluasi kecukupan kontrol serta efektivitas dan efisiensi dari kinerja perusahan.

Peran auditor internal akan semakin diandalkan dalam mengembangkan dan menjaga efektivitas sistem pengendalian internal, pengelolaan resiko untuk mewujudkan suatu perusahaan yang sehat. Tugas auditor internal bukan hanya memeriksa kebenaran perhitungan matematis, tetapi juga meliputi semua aspek [1]. Hal terpenting dari laporan audit internal adalah tentang saran atau rekomendasi yang diajukan pada manajemen dalam rangka melakukan perbaikan dan peningkatan pengelolan yang berpengaruh terhadap prestasi karyawan [2].

Adapun tujuan dari penelitian ini adalah: mengetahui peran auditor internal dalam organisasi PT. Surya Toto Indonesia Tbk., mengetahui cara mengukur kinerja audit internal, mengetahui cara peningkatan kinerja audit internal, mengetahui hasil peningkatan kinerja audit internal.

Yang menjadi batasan masalah dalam penelitian ini adalah: analisis pengukuran dan peningkatan kinerja auditor di seksi Quality Asurance (QA) PT. Surya Toto Indonesia Tbk., penilaian kinerja auditor diukur berdasarkan bobot dan jenis kategori hasil temuan audit, penelitian dilakukan pada bulan Agustus 2015 sampai Oktober 2015.

\section{TINJAUAN PUSTAKA}

Kinerja merupakan hasil kerja yang dicapai oleh seorang pegawai dalam melaksanakan tugas dan tanggung jawabnya. Pada dasarnya pengertian kinerja dapat dimaknai secara beragam. Beberapa pakar memandangnya sebagai hasil dari suatu proses penyelesaian pekerjaan, sementara sebagian yang lain memahaminya sebagai perilaku yang diperlukan untuk mencapai hasil yang diinginkan.

Kinerja juga dapat digambarkan sebagai tingkat pencapaian pelaksanaan suatu kegiatan dalam mewujudkan sasaran, tujuan, misi, visi perusahaan yang tertuang dalam perumusan strategi planning suatu perusahaan. Penilaian tersebut tidak terlepas dari proses yang 
merupakan kegiatan mengolah masukan menjadi keluaran atau penilaian dalam proses penyusunan kebijakan/program/kegiatan yang dianggap penting dan berpengaruh terhadap pencapaian sasaran dan tujuan.

"Performance is what the person or system does" [3]. Hal senada dikemukakan oleh Mohrman et al sebagai berikut: "A performance consists of a performer engaging in behavior in a situation to achieve results" [3]. Dari kedua pendapat ini, terlihat bahwa kinerja dilihat sebagai suatu proses bagaimana sesuatu dilakukan. Jadi, pengukuran kinerja dilihat dari baik-tidaknya aktivitas tertentu untuk mendapatkan hasil yang diinginkan.

Kinerja diartikan sebagai: "Hasil kerja secara kualitas dan kuantitas yang dicapai oleh seorang pegawai dalam melaksanakan tugasnya sesuai dengan tanggung jawab yang diberikan kepadanya. "Sedangkan menurut Hadari yang dimaksud dengan kinerja adalah: "Hasil dari pelaksanaan suatu pekerjaan, baik yang bersifat fisik/mental maupun non fisik/non mental” [5].

Quality Assurance adalah salah satu organisasi departemen atau seksi yang berada di PT. Surya Toto Indonesia Tbk. merupakan (penjaminan mutu) dan semua tindakannya terencana, sistematis dan didemonstrasikan untuk meyakinkan pelanggan bahwa persyaratan yang ditetapkan "akan dijamin" tercapai. Quality Ansurance mempunyai tugas untuk pengendalian sistem dan dokumen resmi yang digunakan untuk semua lini bagian baik lini produksi maupun non produksi dengan tujuan semua kegiatan produksi dan non produksi dapat terkontrol secara kualitas dan kuantitas melalui dokumen resmi yang digunakan pada perusahaan. QA bertangung jawab berjalanya suatu sistem pengendalian kualitas yang harus dipenuhi didalam pembuatan produk dari mulai proses awal hingga akhir sehingga didapatkan output produk dengan kualitas yang terjamin tujuanya. Unsur Quality Assurance (QA) di PT. Surya Toto Indonesia Tbk. terdiri dari: laboratorium kimia dan laboratorium kalibrasi, klaim internal dan eksternal (penanganan pengendalian klaim internal \& eksternal) dan standarisasi, sistem mutu dan AMI.
Internal audit (pemeriksaan intern) adalah pemeriksaan yang dilakukan oleh bagian internal audit perusahaan, baik terhadap laporan keuangan dan catatan akuntansi perusahaan, maupun ketaatan terhadap kebijakan manajemen puncak yang telah ditentukan dan ketaatan terhadap peraturan pemerintah dan ketentuan-ketentuan dari ikatan profesi yang berlaku [6]. Peraturan pemerintah misalnya peraturan di bidang perpajakan, pasar modal, lingkungan hidup, perbankan, perindustrian, investasi dan lain-lain. Ketentuan-ketentuan dari ikatan profesi misalnya standar akuntansi keuangan.

Menurut Mulyadi audit intern adalah auditor yang bekerja dalam perusahaan (perusahaan negara maupun perusahaan swasta) yang tugas pokoknya adalah menentukan apakah kebijakan dan prosedur yang ditetapkan oleh manajemen puncak telah dipatuhi, menentukan baik atau tidaknya penjagaan terhadap kekayaan organisasi, menentukan efisiensi dan efektivitas prosedur kegiatan organisasi, serta menentukan keandalan informasi yang dihasilkan oleh berbagai bagian organisasi [7]. IIA (Institute of Internal auditor) memperkenalkan Standards for the professional Practice of Internal auditing-SPPIA (Standar) [1], audit internal adalah fungsi penilaian independen yang dibentuk dalam perusahaan untuk memeriksa dan mengevaluasi aktivitasaktivitasnya sebagai jasa yang diberikan kepada perusahaan.

Beberapa penelitian tentang internal auditing adalah sebagai berikut:

1. Secara teoritik banyak faktor yang turut mempengaruhi produktivitas kerja pegawai dalam suatu organisasi, antara lain: kualitas sumber daya manusia, sarana dan prasarana yang tersedia, dan lingkungan organisasi baik yang sifatnya eksternal maupun lingkungan organisasi yang sifatnya internal [8].

2. Internal Auditing harus dilaksanakan secara ahli dan dengan ketelitian nasional [9].

3. Audit internal mencakup audit efisiensi, dan program audit tentang efisiensi ditujukan untuk suatu entitas yang telah memperoleh, melindungi dan menggunakan sumber dayanya secara efisien dan efektif [10]. 
4. Kompetensi pegawai berpengaruh tehadap kinerja pegawai. Semakin tinggi kompetensi yang dimiliki oleh pegawai dan sesuai dengan tuntutan pekerjaan maka kinerja pegawai akan semakin meningkat [11].

5. Peran auditor internal yang independen akan sangat penting dalam dalam penerapan Good Corporate Governance dalam suatu perusahaan [12].

\section{METODE PENELITIAN}

Metode penelitian ini adalah dengan cara evaluasi kinerja organisasi departemen Quality Asurance (QA) yang dituangkan pada pedoman kerja QA tahun 2014, yaitu membandingkan target pencapaian dengan hasil yang dicapai pada setiap item karakteristik pedoman kerja QA dalam kurun waktu 1 tahun. Dan salah satu dari karakteristik pada pedoman kerja QA adalah mengukur kinerja audit internal yaitu mengukur jumlah temuan kategori OI (opportunity improvement) dengan target pencapain $15 \%$ dan hasil yang dicapai 1,96\%.

Metode evaluasi adalah suatu upaya untuk mengukur hasil atau dampak suatu aktivitas, program, atau proyek dengan cara membandingkan dengan tujuan yang telah ditetapkan, dan bagaimana cara pencapaiannya [13]. Sedangkan menurut Kurniasih evaluasi adalah sebuah proses dimana keberhasilan yang dicapai dibandingkan dengan seperangkat keberhasilan yang diharapkan [14]. Perbandingan ini kemudian dilanjutkan dengan pengidentifikasian faktor-faktor yang berpengaruh pada kegagalan dan keberhasilan.

Dengan melihat target pencapaian pada pedoman kerja QA tahun 2015, pada item karakateristik mengukur jumlah temuan kategori OI target perusahaan 40\%, maka perlunya peningkatan kinerja audit internal di PT. Surya Toto Indonesia Tbk. Untuk mengidentifikasi berbagai kemungkinan penyebab temuan audit kategori improvement masih rendah, langkah selanjutnya adalah menganalisis masalah tersebut melalui sesi brainstorming yang dituangkan pada fishbone diagram. Setelah menentukan penyebab yang dominan, langkah selanjutnya adalah membuat rencana dan melaksanakan perbaikan $(4 \mathrm{~W}+1 \mathrm{H})$. Hasil dari tindakan perbaikan peningkatan audit internal bisa terlihat pada monitoring pedoman kerja seksi QA tahun 2015 pada bulan juni dan kemudian hasil analisis secara keseluruhan bisa dibuat kesimpulan

\section{HASIL DAN PEMBAHASAN Mengukur Kinerja Audit Internal}

Pengukuran kinerja di PT. Surya Toto Indonesia Tbk. terdiri dari dua pengukuran yaitu pengukuran kinerja karyawan secara personal (individu) dan pengukuran kinerja organisasi atau departemen. Pengukuran kinerja karyawan secara personal adalah menilai atau mengevaluasi hasil kerja karyawan dalam kurun waktu dan karakteristik yang sudah ditentukan perusahaan. Evaluasi atau penilaian karyawan biasanya dalam kurun waktu 1 tahun sekali dan karakteristik yang dinilai diantara lain: Penguasaan kerja, hasil kerja, delivery, tanggung jawab, kerjasama, penyelesaian masalah, absensi, inovasi, K3 dan lain-lain (disesuaikan dengan jenjang atau jabatan yang melekat pada karyawan tersebut).

Pembahasan analisis penelitian kali ini adalah pengukuran kinerja organisasi atau seksi yaitu pengukuran kinerja seksi Quality Assurance (QA) pada sub seksi AMI (audit mutu internal). PT. Surya Toto Indonesia Tbk. dalam mengukur kinerja organisasi atau departemen dilakukan dengan melakukan pengukuran dari hasil pedoman kerja supervisor seksi yang hasil pengukuranya dilakukan setiap bulan dan dievaluasi per 6 bulan pertama (semester 1) dan 6 bulan kedua (semester 2). Pedoman kerja supervisor $Q A$ dibuat berdasarkan Top down dari pedoman kerja direktur dan pedoman kerja manajer yang didalamnya terdiri dari unsur atau item Quality, Cost, Delivery, Safety, Morality, Environment (QCDSME). Karakteristik dan target sasaran serta formula, bisa juga ditentukan berdasarakan project kerja improvement dari seksi $Q A$ sendiri yang disetujui oleh manager dan direktur. Pedoman kerja seksi $Q A$ bisa dilihat seperti pada Tabel 1.

Dari pedoman kerja supervisor seksi $Q A$ tersebut di atas, maka bisa dilihat bahwa hasil kinerja seksi $Q A$ untuk megukur kinerja audit internal terlihat pada item no. 6 yaitu indikatornya adalah jumlah temuan $O I$ 
Tabel 1. Pedoman Kerja Supervisor Seksi QA

\begin{tabular}{|c|c|c|c|c|c|c|c|c|c|}
\hline \multirow[b]{2}{*}{ Item } & \multirow[b]{2}{*}{ No } & \multirow[b]{2}{*}{ Karakteristik yang Diukur } & \multirow[b]{2}{*}{ Ref } & \multirow[b]{2}{*}{ PIC } & \multicolumn{2}{|c|}{ Hasil Tahun 2014} & \multirow{2}{*}{$\begin{array}{c}\text { Target } \\
\text { Tahun 2015 } \\
\text { (Perbulan) }\end{array}$} & \multirow[b]{2}{*}{ Satuan } & \multirow{2}{*}{$\begin{array}{l}\text { Cara } \\
\text { Kontrol }\end{array}$} \\
\hline & & & & & Target & Hasil & & & \\
\hline \multirow{8}{*}{ Q } & 1 & $\begin{array}{l}\text { Perbaikan tindakan klaim } \\
\text { eksternal }\end{array}$ & 98 & Taufik & \multirow[t]{4}{*}{95} & 100 & 100 & Persen & $\begin{array}{c}\text { Form } \\
\text { STIS.22 }\end{array}$ \\
\hline & 2 & $\begin{array}{l}\text { Penurunan temuan klaim } \\
\text { masalah internal }\end{array}$ & 32 & Robihard BB & & 42 & 29(3/bl)n & Masalah & $\begin{array}{l}\text { Form } \\
\text { STIS.22 }\end{array}$ \\
\hline & 3 & $\begin{array}{l}\text { Penurunan kelolosan check } \\
\text { visual casting }\end{array}$ & 95 & Robihard BB & & 107 & 75(7/bln) & Masalah & $\begin{array}{l}\text { Form } \\
\text { STIS.22 }\end{array}$ \\
\hline & 4 & $\begin{array}{l}\text { Penurunan jamlah masalah } \\
\text { visual assembling }\end{array}$ & 110 & Robihard BB & & 129 & 90(8/bln) & Masalah & $\begin{array}{l}\text { Form } \\
\text { STIS.22 }\end{array}$ \\
\hline & 5 & $\begin{array}{l}\text { Pelaksanan audit internal dan } \\
\text { pedoman kerja }\end{array}$ & 100 & M. Solihudin & 100 & 100 & 100 & Persen & $\begin{array}{l}\text { Form } \\
\text { STIS.22 }\end{array}$ \\
\hline & 6 & $\begin{array}{l}\text { Jumlah temuan kategori OI } \\
\text { (Improvement) }\end{array}$ & 35 & M. Solihudin & 15 & 1,96 & 40 & Persen & $\begin{array}{l}\text { Form } \\
\text { STIS.22 }\end{array}$ \\
\hline & 7 & Verifikasi hasil audit internal & 100 & M. Solihudin & 98 & 100 & 100 & Persen & $\begin{array}{l}\text { Form } \\
\text { STIS.22 }\end{array}$ \\
\hline & 8 & $\begin{array}{l}\text { Verifikasi temuan hasil audit } \\
\text { pedoman kerja }\end{array}$ & 100 & M. Solihudin & 95 & 100 & 100 & Persen & $\begin{array}{l}\text { Form } \\
\text { STIS.22 }\end{array}$ \\
\hline & 9 & Cost Reduction QA & $5 \mathrm{jt}$ & Muttakim & $3 \mathrm{Jt} / \mathrm{thn}$ & 6.038 .413 & $3 \mathrm{jt} / \mathrm{thn}$ & Rupiah & $\begin{array}{c}\text { Form } \\
\text { STIS.22 }\end{array}$ \\
\hline C & 10 & $\begin{array}{l}\text { Penyelesaian masalah klaim } \\
\text { eksternal yang tepat waktu ( } 2 \\
\text { hari kerja) }\end{array}$ & 100 & Taufik & 100 & 100 & 100 & Persen & $\begin{array}{l}\text { Form } \\
\text { STIS.22 }\end{array}$ \\
\hline
\end{tabular}

\section{Keterangan:}

(;): Target tercapai

(): Taget tidak tercapai

Tabel 2. Hasil Evaluasi Pedoman Kerja Seksi

\begin{tabular}{|c|c|c|c|c|c|c|c|c|c|c|}
\hline \multirow{3}{*}{ Item } & \multirow{3}{*}{ No } & \multirow{3}{*}{$\begin{array}{l}\text { Karakteristik yang } \\
\text { Diukur }\end{array}$} & \multirow{3}{*}{$\begin{array}{c}\text { Target } \\
\text { Tahun } 2015 \\
\text { (Perbulan) }\end{array}$} & \multirow{3}{*}{ Satuan } & \multicolumn{6}{|c|}{ Bulan 2015} \\
\hline & & & & & \multicolumn{2}{|c|}{ Januari } & \multicolumn{2}{|c|}{ Februari } & \multicolumn{2}{|c|}{ Maret } \\
\hline & & & & & Hasil & Simbol & Hasil & Simbol & Hasil & Simbol \\
\hline \multirow{8}{*}{$\mathrm{Q}$} & 1 & $\begin{array}{l}\text { Perbaikan tindakan } \\
\text { klaim eksternal }\end{array}$ & 100 & Persen & 100 & (:) & 100 & (:) & 100 & (;) \\
\hline & 2 & $\begin{array}{l}\text { Penurunan temuan klaim } \\
\text { masalah internal }\end{array}$ & 29 (3/bln) & Masalah & 3 & (:) & 2 & (:) & 1 & (:) \\
\hline & 3 & $\begin{array}{l}\text { Penurunan kelolosan } \\
\text { check visual casting }\end{array}$ & 75 (7/bln) & Masalah & 15 & (2) & 6 & (:) & 5 & (:) \\
\hline & 4 & $\begin{array}{l}\text { Penurunan jamlah } \\
\text { masalah visual } \\
\text { assembling }\end{array}$ & 90 (8/bln) & Masalah & 7 & (;) & 7 & (:) & 4 & (;) \\
\hline & 5 & $\begin{array}{l}\text { Pelaksanan audit internal } \\
\text { dan pedoman kerja }\end{array}$ & 100 & Persen & & (;) & & (:) & & (;) \\
\hline & 6 & $\begin{array}{l}\text { Jumlah temuan kategori } \\
\text { OI (Imptovement) }\end{array}$ & 40 & Persen & & (;) & & (:) & & (;) \\
\hline & 7 & $\begin{array}{l}\text { Verifikasi hasil audit } \\
\text { internal }\end{array}$ & 100 & Persen & & (;) & & (:) & & (:) \\
\hline & 8 & $\begin{array}{l}\text { Verifikasi temuan hasil } \\
\text { audit pedoman kerja }\end{array}$ & 100 & Persen & & (;) & & (;) & & (;) \\
\hline & 9 & Cost Reduction QA & $\begin{array}{c}3 \mathrm{jt} / \mathrm{thn} \\
(250 \mathrm{rb} / \mathrm{bln})\end{array}$ & Rupiah & 316.042 & (;) & 209.188 & (2) & 326.327 & (;) \\
\hline $\mathrm{C}$ & 10 & $\begin{array}{l}\text { Penyelesaian masalah } \\
\text { klaim eksternal yang } \\
\text { tepat waktu ( } 2 \text { hari kerja) }\end{array}$ & 100 & Persen & & ;) & 100 & (:) & 100 & () \\
\hline
\end{tabular}

(improvement) dengan target pencapaian 40\%. Hasil pengukuran pedoman kerja tiap bulannya dilaporkan pada manajer dan direktur yang hasilnya bisa terlihat pada monitoring pedoman kerja supervisor.

Dari hasil evaluasi tersebut, di atas terlihat nilai hasil yang dicapai setiap bulannya. Untuk karakateristik dari item kontrol yang tercapai maka akan dipasang simbol tersenyum, dan untuk yang tidak tercapai akan dipasang simbol menangis maka hasil kinerja seksi Quality assurance (QA) dapat terlihat perolehan hasil kinerjanya berdasarkan target sasaran yang sudah ditetapkan.

\section{Kegiatan Audit Internal}

Kegiatan audit internal di PT. Surya Toto Indonesia Tbk. dilakukan setiap tahun semenjak 
Tabel 3. Data Temuan Audit Internal Tahun 2012 2014

\begin{tabular}{|c|c|c|c|c|c|}
\hline \multirow{2}{*}{ Tahun } & \multirow{2}{*}{$\begin{array}{c}\text { Total } \\
\text { Temuan }\end{array}$} & \multicolumn{2}{|c|}{ Jumlah Kategori Temuan } & \multirow{2}{*}{$\begin{array}{c}\text { Kesesuaian } \\
(\%)\end{array}$} & \multirow{2}{*}{$\begin{array}{c}\text { Improvement } \\
(\%)\end{array}$} \\
\hline & & Kesesuaian & Improvement & & \\
\hline 2012 & 186 & 178 & 8 & 95,70 & 4,30 \\
\hline 2013 & 161 & 143 & 18 & 88,82 & 11,18 \\
\hline 2014 & 2014 & 200 & 4 & 98,04 & 1,96 \\
\hline Total & 551 & 521 & 30 & 94,56 & 5,44 \\
\hline \multicolumn{2}{|c|}{ Rata-rata/Tahun } & 174 & 10 & & \\
\hline
\end{tabular}

perusahaan mendapatkan sertifikasi ISO 9001:2008 pada tahun 2000. Kegiatan audit internal dilakukan karena merupakan salah satu persyaratan dari sertifikasi ISO 9001:2008 pada klausul 8.2.2 yaitu perusahaan harus melakukan audit internal pada jangka waktu yang terencana.

Temuan hasil audit internal selalu dilaporkan pada manajemen baik jumlah temuan serta kategori temuan, yang tujuannya adalah untuk evaluasi manajemen terkait dengan perbaikan manajemen mutu yang sudah dilakukan setiap bagaian atau seksi dalam organisasi perusahaan. Tabel 3 adalah data hasil temuan audit PT. Surya Toto Indonesia Tbk. dari tahun 2012 sampai tahun 2014.

Dua kategori dari hasil temuan audit internal PT. Surya Toto Indonesia Tbk. yaitu kategori kesesuaian adalah melihat kesesuaian proses secara aktual dibandingkan dengan persyaratan pada standar yang ditentukan dan dan kategori improvement adalah temuan audit yang sifatnya Opportunity Improvement untuk Perbaikan sistem atau proses peningkatan kinerja dari proses kerja tersebut. Dua kategori tersebut prosentasenya digambarkan pada Gambar 1.

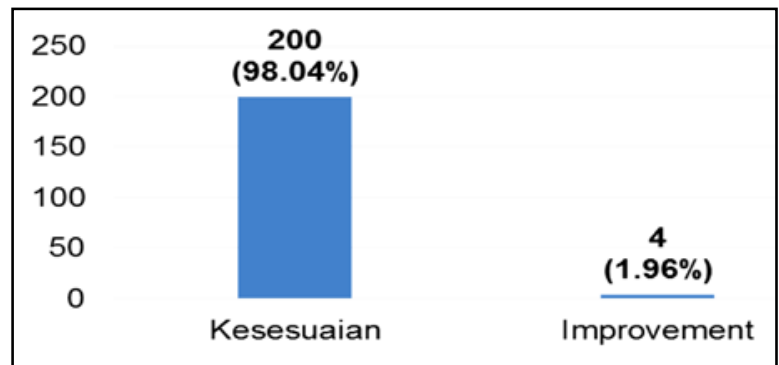

Gambar 1. Temuan Audit Internal Berdasarkan Kategori Seksi Quality Asurance (QA) Tahun 2014

\section{Target KPI audit internal tahun 2015}

Untuk menjamin kepuasan pelanggan baik dari segi jasa pelayanan maupun infrastruktur penunjangnya. Dengan demikian PT. Surya Toto Indonesia Tbk. perlu menyiapkan kerangka sistem mutu untuk mampu mencapai kesesuaian dengan keinginan yang diharapkan dari pelanggan, serta melakukan continuous improvement di segala bidang. Untuk menunjang hal tersebut di tahun

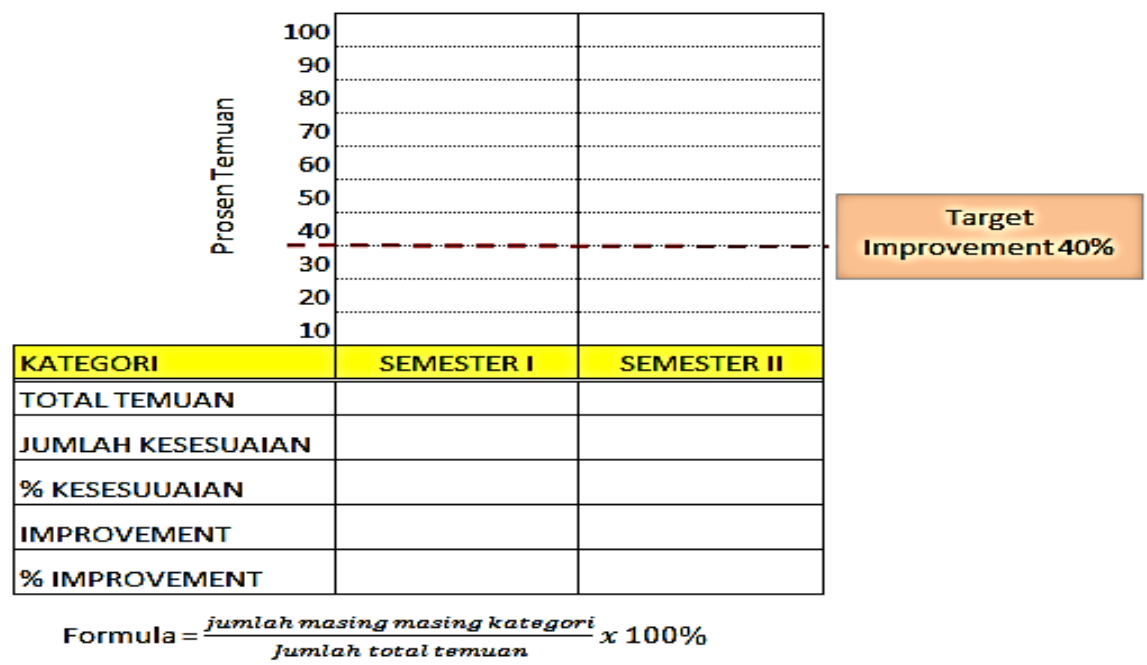

Gambar 2. Grafik Monitoring Target Hasil Temuan Audit 
2015 perusahaan menentukan target dari hasil temuan audit intenal untuk kategori (OI) opportunity improvement prosentasenya $40 \%$ dari jumlah temuan audit internal yang dilakukan, target dan formula tersebut bisa dilihat pada pedoman kerja supervisor dan grafik monitoring target kinerja $Q A$ sub AMI (audit mutu internal) pada Gambar 2.

Berdasarkan yang data Audit Internal tahun 2014 terlihat pada Gambar 2. Jumlah temuan kategori Improvement masih rendah yaitu 1,96\% dari jumlah total temuan audit serta mempertimbangkan target manajemen yang dituangkan dalam pedoman kerja supervisor $Q A$ yaitu target temuan audit kategori improvement adalah $40 \%$ dari jumlah total temuan audit, maka keputusan manajemen untuk peningkatan kinerja dari audit internal PT. Surya Toto Indonesia Tbk.

\section{Menganalisis Masalah dengan Diagram Sebab Akibat}

Untuk mengidentifikasi berbagai kemungkinan penyebab temuan audit kategori improvement masih rendah, langkah selanjutnya adalah menganalisis masalah tersebut melalui sesi brainstorming yang dituangkan pada fishbone diagram. Masalah akan dipecah menjadi sejumlah kategori yang berkaitan, mencakup manusia, material, metode, mesin, dan lingkungan. Setiap kategori mempunyai sebab-sebab yang perlu diuraikan melalui sesi brainstorming seperti pada Gambar 3.

\section{Menguji dan Menentukan Penyebab Dominan}

Pada diagram tulang ikan atau diagram sebab akibat lihat Gambar 4 ditemukan 12 penyebab akar masalah, dari 12 masalah tersebut harus ditentukan penyebab dominan agar perbaikan yang dilakukan tepat sasaran.

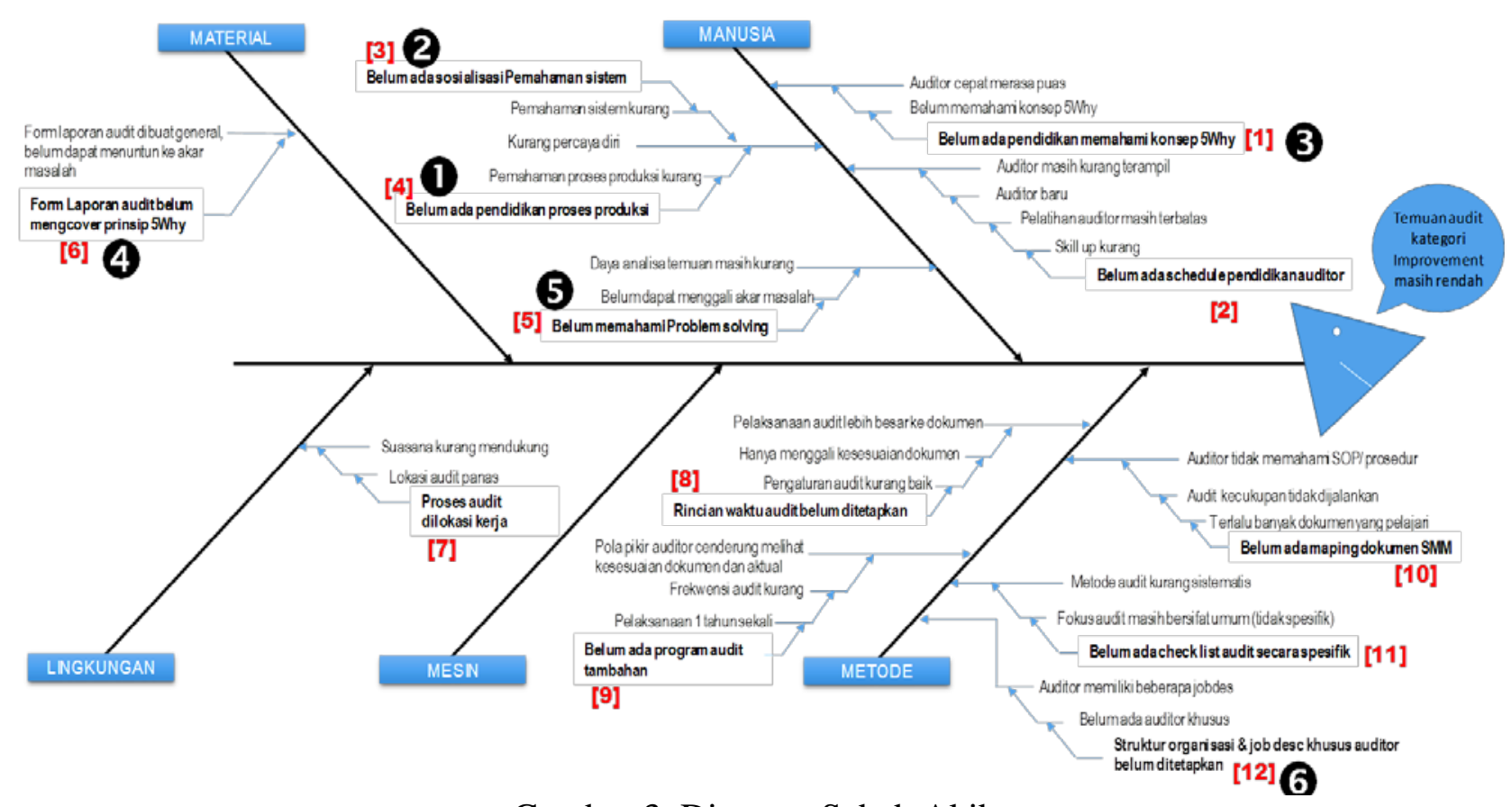

Gambar 3. Diagram Sebab Akibat

Tabel 4. Data Pengujian Penyebab Dominan

\begin{tabular}{|c|c|c|c|c|c|c|c|c|c|c|c|c|c|}
\hline \multirow{2}{*}{ No } & \multirow{2}{*}{ Penyebab } & \multicolumn{10}{|c|}{ Bulan } & \multirow{2}{*}{ Total } & \multirow{2}{*}{ Rangking } \\
\hline & & 1 & 2 & 3 & 4 & 5 & 6 & 7 & 8 & 9 & 10 & & \\
\hline 1 & Belum ada pendidikan tentang 5 Why & 7 & 8 & 10 & 2 & 9 & 10 & 5 & 9 & 11 & 9 & 80 & III \\
\hline 2 & $\begin{array}{l}\text { Belum ada schedule penididikan } \\
\text { auditor }\end{array}$ & 11 & 4 & 4 & 1 & 3 & 11 & 4 & 4 & 4 & 3 & 49 & \\
\hline 3 & $\begin{array}{l}\text { Belum ada sosialisasi pemahaman } \\
\text { sistem }\end{array}$ & 9 & 7 & 7 & 3 & 12 & 9 & 6 & 10 & 10 & 10 & 83 & II \\
\hline 4 & $\begin{array}{l}\text { Belum ada pendidikan proses } \\
\text { produksi }\end{array}$ & 12 & 5 & 6 & 11 & 11 & 8 & 8 & 12 & 12 & 12 & 97 & I \\
\hline
\end{tabular}


Lanjutan Tabel 4. Data Pengujian Penyebab Dominan

\begin{tabular}{|c|c|c|c|c|c|c|c|c|c|c|c|c|c|}
\hline \multirow{2}{*}{ No } & \multirow{2}{*}{ Penyebab } & \multicolumn{10}{|c|}{ Bulan } & \multirow{2}{*}{ Total } & \multirow{2}{*}{ Rangking } \\
\hline & & 1 & 2 & 3 & 4 & 5 & 6 & 7 & 8 & 9 & 10 & & \\
\hline 5 & Belum Memahami Problem Solving & 3 & 9 & 11 & 7 & 4 & 7 & 11 & 6 & 6 & 5 & 69 & VI \\
\hline 6 & $\begin{array}{l}\text { Form Laporan Audit belum } \\
\text { mengcover Prinsip } 5 \text { Why }\end{array}$ & 4 & 3 & 9 & 5 & 8 & 12 & 2 & 11 & 9 & 11 & 74 & IV \\
\hline 7 & Proses Audit dilokasi Kerja & 2 & 2 & 5 & 6 & 6 & 2 & 10 & 7 & 2 & 7 & 49 & \\
\hline 8 & $\begin{array}{l}\text { Rincian Waktu Audit belum } \\
\text { ditetapkan }\end{array}$ & 1 & 1 & 12 & 8 & 1 & 4 & 9 & 5 & 1 & 6 & 48 & \\
\hline 9 & $\begin{array}{l}\text { Belum Ada Program Audit } \\
\text { Tambahan }\end{array}$ & 5 & 10 & 2 & 12 & 2 & 6 & 12 & 1 & 8 & 1 & 59 & \\
\hline 10 & Belum Ada Mapping Dokumen SMM & 6 & 11 & 3 & 9 & 7 & 3 & 3 & 2 & 3 & 2 & 49 & \\
\hline 11 & $\begin{array}{l}\text { Belum Ada Check List Audit Secara } \\
\text { Spesifik }\end{array}$ & 8 & 12 & 1 & 10 & 5 & 5 & 1 & 3 & 7 & 4 & 56 & \\
\hline 12 & $\begin{array}{l}\text { Struktur Organisasi \& Job Deskc } \\
\text { khusus Auditor Belum Ditetapkan }\end{array}$ & 10 & 6 & 8 & 4 & 10 & 1 & 7 & 8 & 5 & 8 & 67 & V \\
\hline
\end{tabular}

Untuk menentukan penyebab dominan, mengacu pada rumus (1) di bawah

$\geq \frac{1}{2} N+1$ dimana $N=\sum$ Penyebab $x \sum$ Penilai

$\geq 1 / 2(12 x 10)+1$

$\geq 1 / 2 \times 120+1 \geq 1 / 2 \times 120+1$

$\geq 61$
Berdasarkan hasil pengujian maka dapat disimpulkan bahwa penyebab dominan adalah seperti terlihat pada Tabel 5.

Setelah menentukan penyebab yang dominan, langkah selanjutnya adalah Membuat rencana dan melaksanakan perbaikan $(4 \mathrm{~W}+1 \mathrm{H})$ seperti terlihat pada Tabel 6 .

Tabel 5. Data Penyebab Dominan Hasil Temuan Audit Internal Kategori Improvement Rendah

\begin{tabular}{cllcc}
\hline No & & \multicolumn{1}{c}{ Penyebab } & Total & Ranking \\
\hline 1 & Manusia & Belum ada pendidikan proses produksi & 97 & I \\
2 & Manusia & Belum ada sosialisasi pemahaman sistem & 83 & II \\
3 & Manusia & Belum ada pendidikan memahami konsep 5 Why & 80 & II \\
4 & Material & Form laporan audit mengcover prinsip 5 Why & 74 & IV \\
5 & Manusia & Belum memahami probem solving & 69 & V \\
6 & Metode & Struktur organisasi \& job desc khusus auditor belum ditetapkan & 67 & VI \\
\hline
\end{tabular}

Tabel 6. Data Rencana dan Melaksanakan Perbaikan $(4 \mathrm{w}+1 \mathrm{H})$

\begin{tabular}{|c|c|c|c|c|c|c|c|c|}
\hline & & & Why & What & Where & When & Who & How \\
\hline No & Faktor & Penyebab & $\begin{array}{c}\text { Mengapa harus } \\
\text { diperbaiki }\end{array}$ & $\begin{array}{c}\text { Apa yang harus } \\
\text { diperbaiki }\end{array}$ & $\begin{array}{c}\text { Dimana } \\
\text { dikerjakan }\end{array}$ & $\begin{array}{c}\text { Kapan } \\
\text { dilaksanakan } \\
\end{array}$ & $\begin{array}{c}\text { Siapa } \\
\text { pelaksananya }\end{array}$ & $\begin{array}{c}\text { Bagaimana } \\
\text { caranya }\end{array}$ \\
\hline 1 & \multirow{4}{*}{$\begin{array}{l}\text { Manu } \\
\text { sia }\end{array}$} & $\begin{array}{l}\text { Belum ada } \\
\text { pendidikan proses } \\
\text { produksi }\end{array}$ & $\begin{array}{l}\text { Supaya } \\
\text { memahami proses } \\
\text { produksi }\end{array}$ & $\begin{array}{l}\text { Melakukan pendidikan } \\
\text { pemahaman proses } \\
\text { produksi dari seksi } \\
\text { Casting s/d Ass'y }\end{array}$ & HRD-TR & $\begin{array}{c}\text { 24-29 } \\
\text { Agust ‘15 }\end{array}$ & $\begin{array}{l}\text { HRD-TR + } \\
\text { Seksi }\end{array}$ & $\begin{array}{l}\text { Dilakukan training } \\
\text { oleh instruktur dari } \\
\text { seksi }\end{array}$ \\
\hline 2 & & $\begin{array}{l}\text { Belum ada } \\
\text { sosialisasi } \\
\text { pemahaman } \\
\text { sistem } \\
\end{array}$ & $\begin{array}{l}\text { Supaya } \\
\text { memahami } \\
\text { Sistem STI }\end{array}$ & $\begin{array}{l}\text { Melakukan sosialisasi } \\
\text { pemahaman sistem } \\
\text { (STI dan prosedur) }\end{array}$ & $\begin{array}{c}\text { QA } \\
\text { Sistem }\end{array}$ & $\begin{array}{l}\text { 01-11 Sept } \\
\text { '15 }\end{array}$ & Hartono & $\begin{array}{l}\text { Penyampaian } \\
\text { materi diskusi dan } \\
\text { evaluasi }\end{array}$ \\
\hline \multirow{2}{*}{3} & & $\begin{array}{l}\text { Belum ada } \\
\text { pendidikan } \\
\text { memahami } \\
\text { konsep } 5 \text { Why } \\
\end{array}$ & $\begin{array}{l}\text { Supaya } \\
\text { memahami } \\
\text { konsep } 5 \text { Why }\end{array}$ & $\begin{array}{l}\text { Membuat form } \\
\text { pencatatan hasil audit } \\
\text { dan melakukan } \\
\text { pemahaman }\end{array}$ & $\begin{array}{c}\text { QA } \\
\text { Sistem }\end{array}$ & 10 Juli ‘'15 & Hartono & $\begin{array}{l}\text { Menjelaskan } \\
\text { contoh dan cara } \\
\text { pengisian format } \\
\text { baru }\end{array}$ \\
\hline & & $\begin{array}{l}\text { belum memahami } \\
\text { problem solving }\end{array}$ & $\begin{array}{l}\text { Supaya } \\
\text { memahami } \\
\text { problem solving }\end{array}$ & $\begin{array}{l}\text { Buat materi dan } \\
\text { melakukan pendidikan } \\
\text { problem solving }\end{array}$ & $\begin{array}{c}\text { QA } \\
\text { Sistem }\end{array}$ & 10 Sept '15 & Hartono & $\begin{array}{l}\text { Membuat materi } \\
\text { problem solving } \\
\text { dan penyampaian } \\
\text { materi }\end{array}$ \\
\hline 4 & $\begin{array}{l}\text { Mate } \\
\text { rial }\end{array}$ & $\begin{array}{l}\text { Form laporan } \\
\text { audit mengcover } \\
\text { prinsip } 5 \text { Why }\end{array}$ & $\begin{array}{l}\text { Untuk } \\
\text { memudahkan } \\
\text { guide dalam } \\
\text { proses audit } \\
\end{array}$ & $\begin{array}{l}\text { Membuat form } \\
\text { pencatatan hasil audit } \\
\text { dan melakukan } \\
\text { pemahaman }\end{array}$ & $\begin{array}{c}\text { QA } \\
\text { Sistem }\end{array}$ & 9 Juli ‘15 & Hartono & $\begin{array}{l}\text { Membuat format } \\
\text { baru }\end{array}$ \\
\hline 5 & Metode & $\begin{array}{l}\text { Struktur } \\
\text { organisasi \& job } \\
\text { desc khusus } \\
\text { auditor belum } \\
\text { ditetapkan }\end{array}$ & $\begin{array}{l}\text { Supaya fokus } \\
\text { dalam } \\
\text { pelaksanaan audit }\end{array}$ & $\begin{array}{l}\text { Perbaiki struktur } \\
\text { organisasi dan buat job } \\
\text { desc khusus auditor }\end{array}$ & $\begin{array}{c}\text { QA } \\
\text { Sistem }\end{array}$ & 1 Okt '15 & Hartono & $\begin{array}{l}\text { Merevisi struktur } \\
\text { dan membuat } \\
\text { tugas dan } \\
\text { tanggung jawab }\end{array}$ \\
\hline
\end{tabular}




\section{PENINGKATAN KINERJA AUDIT INTERNAL}

Seksi QA (Quality Asurance) dalam membuat program peningkatkan kinerja audit internal diantaranya, dengan melakukan pelatihan-pelatihan untuk personal auditor internal dengan materi meliputi: proses produksi, pemahaman sistem, konsep 5 why dan problem sloving, seperti terlihat pada Gambar 4.

Selain membekali dengan pengetahuan yang diperlukan oleh auditor internal, untuk mempermudah proses audit internal maka perlu dibuatkan form laporan pemeriksaan audit seperti Gambar 5.
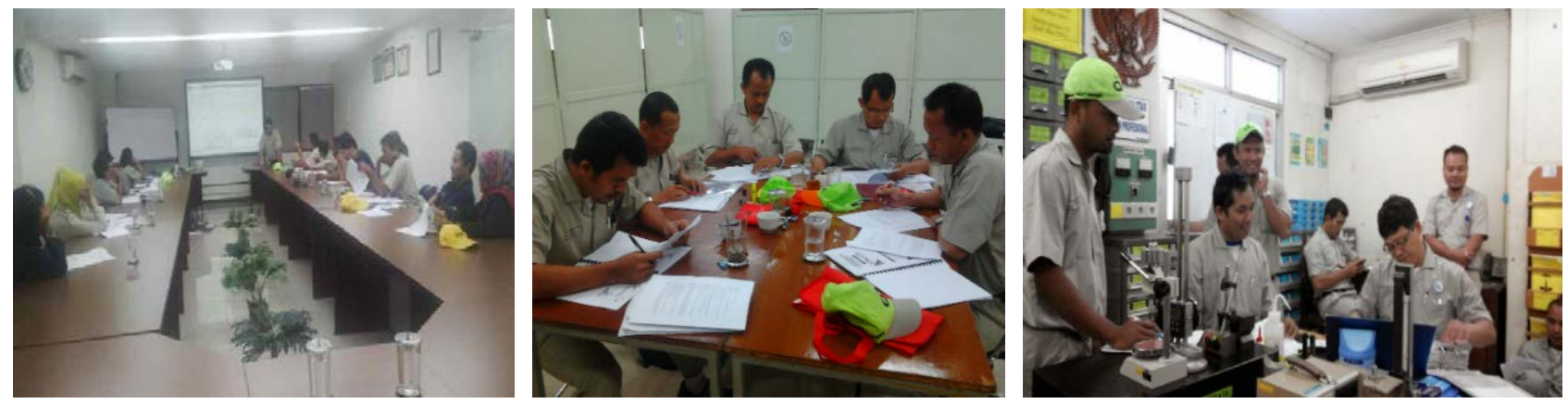

Gambar 4. Pelatihan Auditor Internal PT. Surya Toto Indonesia Tbk.

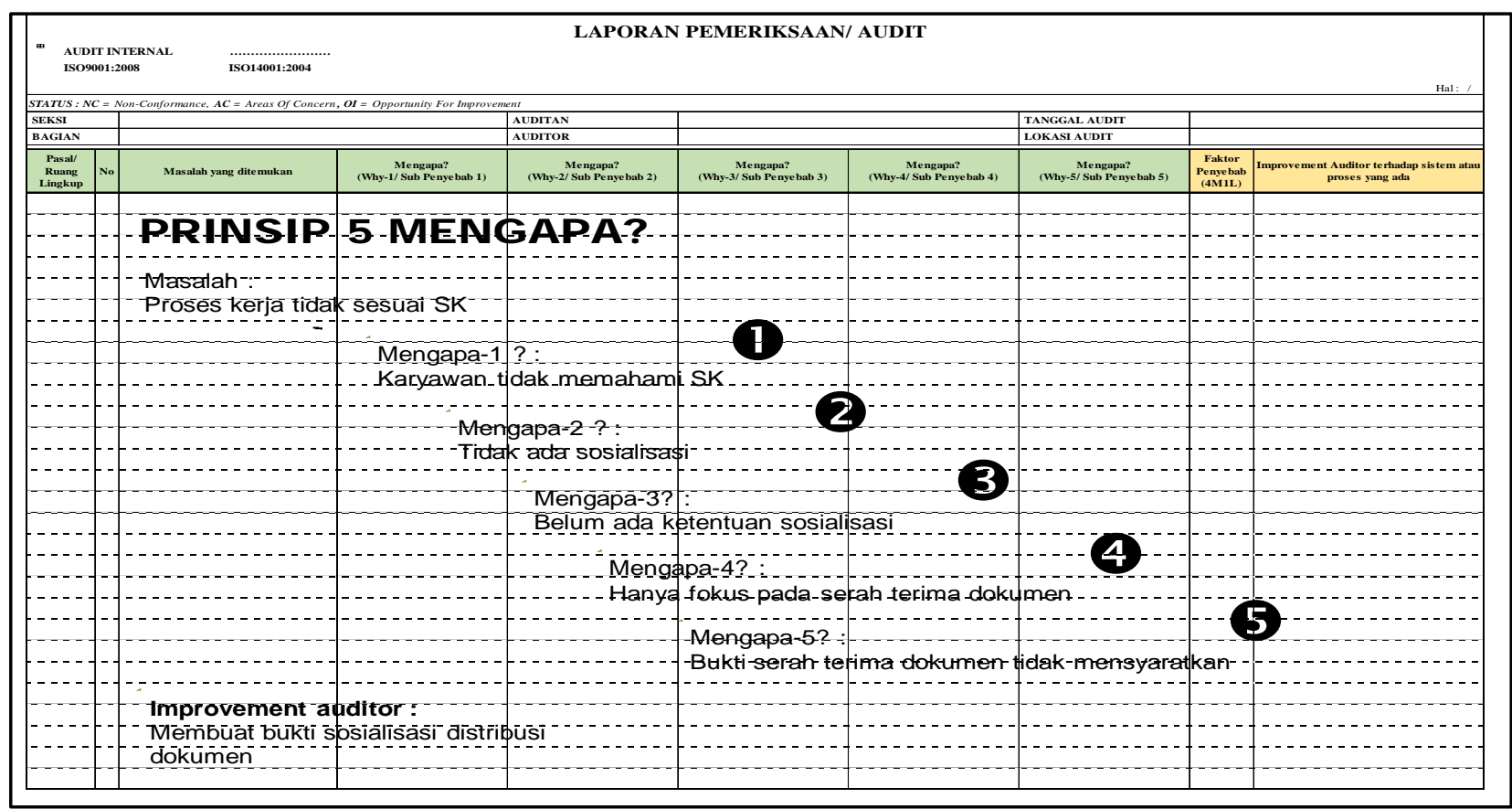

Gambar 5. Formulir Laporan Pemeriksaan Audit

\section{Hasil Peningkatan Kinerja Audit internal}

Setelah seksi Quality Asurance (QA) melakukan pelatihan-pelatihan auditor internal dengan materi seperti yang dibahas dalam menentukan penyebab dominan, maka hasil dari tindakan perbaikan peningkatan audit internal bisa terlihat dalam monitoring pedoman kerja seksi QA seperti Tabel 7.

Dari hasil monitoring pedoman kerja supervisor seksi Quality Asurance (QA), terlihat bahwa kinerja audit internal indikatornya pada pedoman kerja no. 6 yaitu jumlah temuan audit internal kategori OI (Opportunity improvement) target perusahaan adalah $40 \%$ dari total temuan audit internal dan pencapaian hasil pada semester I terlihat pada bulan Juni hasil pencapainnya $41 \%$. 
Tabel 7. Hasil Evaluasi Pedoman Kerja Seksi

\begin{tabular}{|c|c|c|c|c|c|c|c|c|c|c|}
\hline \multirow{3}{*}{ Item } & \multirow{3}{*}{ No } & \multirow{3}{*}{$\begin{array}{l}\text { Karakteristik yang } \\
\text { Diukur }\end{array}$} & \multirow{3}{*}{$\begin{array}{l}\text { Target } \\
\text { Tahun } \\
2015 \\
\text { (Perbulan) }\end{array}$} & \multirow{3}{*}{ Satuan } & \multicolumn{6}{|c|}{ Bulan 2015} \\
\hline & & & & & \multicolumn{2}{|c|}{ Januari } & \multicolumn{2}{|c|}{ Februari } & \multicolumn{2}{|c|}{ Maret } \\
\hline & & & & & Hasil & Simbol & Hasil & Simbol & Hasil & Simbol \\
\hline \multirow{8}{*}{ Q } & 1 & $\begin{array}{l}\text { Perbaikan tindakan } \\
\text { klaim eksternal }\end{array}$ & 100 & Persen & 100 & (-) & 100 & (:) & 100 & (-) \\
\hline & 2 & $\begin{array}{l}\text { Penurunan temuan } \\
\text { klaim masalah } \\
\text { internal }\end{array}$ & 29(3/bln) & Masalah & 2 & (-) & 2 & (-) & 1 & (:) \\
\hline & 3 & $\begin{array}{l}\text { Penurunan kelolosan } \\
\text { check visual casting }\end{array}$ & 75(7/bln) & Masalah & 7 & (-) & 4 & (-) & 5 & (-) \\
\hline & 4 & $\begin{array}{l}\text { Penurunan jamlah } \\
\text { masalah visual } \\
\text { assembling }\end{array}$ & $90(8 / b \ln )$ & Masalah & 6 & (-) & 6 & + & 5 & (:) \\
\hline & 5 & $\begin{array}{l}\text { Pelaksanan audit } \\
\text { internal dan pedoman } \\
\text { kerja }\end{array}$ & 100 & Persen & & (-) & 100 & (-) & 100 & (-) \\
\hline & 6 & $\begin{array}{l}\text { Jumlah temuan } \\
\text { kategori OI } \\
\text { (Imptovement) }\end{array}$ & 40 & Persen & & () & 32 & (2) & 41 & (:) \\
\hline & 7 & $\begin{array}{l}\text { Verifikasi hasil audit } \\
\text { internal }\end{array}$ & 100 & Persen & & (-) & 100 & (;) & 100 & $\odot$ \\
\hline & 8 & $\begin{array}{l}\text { Verifikasi temuan } \\
\text { hasil audit pedoman } \\
\text { kerja }\end{array}$ & 100 & Persen & & (-) & 100 & (-) & 100 & (-) \\
\hline & 9 & Cost Reduction QA & $\begin{array}{c}3 \mathrm{jt} / \mathrm{thn} \\
(250 \mathrm{rb} / \mathrm{bln})\end{array}$ & Rupiah & 415.000 & (-) & 325.000 & (-) & 285.000 & (-) \\
\hline $\mathrm{C}$ & 10 & $\begin{array}{l}\text { Penyelesaian masalah } \\
\text { klaim eksternal yang } \\
\text { tepat waktu ( } 2 \text { hari } \\
\text { kerja) }\end{array}$ & 100 & Persen & & (-) & 100 & (-) & 100 & (-) \\
\hline
\end{tabular}

\section{KESIMPULAN}

Peran audit internal bagi perusahaan sangat penting, selain memberikan informasi dan saran-saran kepada manajemen atas kelemahan-kelemahan yang ditemukannya. Dengan peningkatan kinerja audit internal dalam rangka meningkatkan jumlah temuan audit kategori improvement, maka peran audit internal membantu perusahaan untuk memeberikan masukan kepada seksi atau organisasi yang diaudit terkait temuan kategori improvement sebagai salah satu program perusahaan yang berkelanjutan. Cara mengukur kinerja audit internal yaitu dengan cara mengukur hasil pedoman kerja supervisor seksi. Didalamnya terdiri dari unsur atau item Quality, Cost, Delivery, Safety, Morality, Environment (QCDSME). Di dalam item quality karakteristik yang diukur salah satunya yaitu jumlah temuan audit internal kategori OI (opportunity improvement) dengan target perusahaan 40\% sebagai indikator kinerja audit internal sangat baik. Peningaktan kinerja audit internal dapat dilakukan dengan cara melakukan pelatihan terhadap personal auditor internal yaitu pendidikan proses produksi, pemahaman sistem, konsep 5 why, problem solving serta membuat form laporan audit dengan konsep 5 why dan menentukan job description audit internal, sehingga personal auditor internal akan lebih mudah dalam menggali kemungkinan-kemungkinan seksi atau organisasi yang diaudit untuk melakukan improvement. Dari hasil monitoring pedoman kerja supervisor seksi, terlihat bahwa kinerja audit internal dengan jumlah temuan audit internal kategori OI (Opportunity improvement) target perusahaan adalah $40 \%$ dari total temuan audit internal dengan adanya peningkatan kinerja audit internal, pencapaian hasil pada semester I terlihat pada bulan Juni hasil pencapainnya $41 \%$.

\section{DAFTAR PUSTAKA}

[1]. Sawyer, L. B., Mortimer A., Dittenhofer, J. H, \& Scheiner. 2005, Audit Internal Sawyer, Edisi 5, Alih Bahasa: Desi Adhariani. Salemba Empat, Jakarta. 
[2]. Anggraini, F., 2008, Analisis Pengaruh Peran Auditor Internal Terhadap Peningkatan Pengendalian Intern dan Kinerja Perusahaan. Jakarta: Skripsi Universitas Islam Negeri Syarif Hidayatullah.

[3]. Williams, R., 2002, Managing Employee Performance: Design and Implementation in Organization, London: Thomson Learning.

[4]. Mangkunegara, A. P., 2000, Manajemen Sumber Daya Manusia Perusahaan, Bandung: Penerbit PT, Remaja Rosdakarya.

[5]. Agoes, S., 2004, Auditing (Pemeriksaan Akuntan) oleh Kantor Akuntan Publik, Edisi ketiga, Jilid II, Jakarta: Lembaga Penerbit Fakultas Ekonomi Indonesia.

[6]. Hadari, N. H., 199, Manajemen Sumber Daya Manusia, Yogyakarta: Penerbit Gajah Mada University Press.

[7]. Mulyadi, 2002, Auditing, Edisi 6, Buku 1, Jakarta: Salemba Empat.

[8]. Kamuli, S., 2012, Pengaruh Iklim Organisasi Terhadap Produktivitas Kerja Pegawai di Sekretariat Daerah Kota Gorontalo, Jurnal Inovasi, Vol. 09, N1. 01, pp. 1-8.

[9]. Siwahjoeni, 2011, Evaluasi Fungsi Internal Auditor Dalam Meningkatkan Efektifitas Bank, Jurnal Keuangan dan Perbankan, Vol.15, No.3, pp. 466-478.
[10]. Hermawan, A., 2010, Pengaruh Auditor Eksternal dan Auditor Internal pada Pelaksanaan Good Corporate Governance, Trikonomika, Volume 9, No. 1, pp. 3747.

[11]. Sujana, E., 2012, Pengaruh Kompetensi, Motivasi, Kesesuaian Peran dan Komitmen Organisasi Terhadap Kinerja Auditor Internal Inspktorat Pemerintah Kabupaten Buleleng, Jurnal Ilmiah Akunsi dan Humanika (JINAH), Vol. 2, No.1, pp. 1-27.

[12]. Putra, V. D. C., 2014, Peran Auditor Internal Dalam Upaya Mewujudkan Good Corporate Governance (Studi pada PDAM Tirtawening Kota Bandung), Bandung: Skripsi Universitas Widyatama.

[13]. Mulyono, 2009, Penelitian Eveluasi Kebijakan, http://mulyono.staff.uns.ac.id /2009/05/13/penelitian - evaluasi kebijakan/, Diakses 11 Oktober 2015.

[14]. Kurniasih, R. D., 2009, Teknik Evaluasi Perencanaan, http://images.rikania09. multiply.multiplycontent.com/attachment/ 0/SUdfiwoKCF8AADuyo-81/Rika\%20 Eva.doc?nmid=148657139, Diakses 11 Oktober 2015) 